\title{
Oil extraction and derivatization method: a review
}

\begin{abstract}
The objective of this work is to analyze and present the main methods of oil extraction. The present study suggests that different methods could be used to extract oil for food and feed purposes. The method to be used for the extraction depends on several factors, among which its cost and the materials to be used stand out. This work has reviewed wellknown and widely practiced methods of oil extraction namely and conventional methods (solvent extraction), as well as new innovative methods aimed at raising and optimizing oil yield and improving oil quality. The main derivatization methods are also reviewed since among edible oils the determination of fatty acids is one of the quality parameters most studied and disseminated in the scientific literature. Major shortcomings associated with the conventional methods are solvent consumption, extraction time lag and adverse thermal effects at high temperatures that can produce oxidative processes of lipids. New techniques such as microwave-assisted extraction, ultrasonic-assisted extraction, and supercritical fluid extraction have been developed, and are being used to effectively reduce these shortcomings. Although, as previously stated, the researchers apply the most feasible, least-cost method that suits their research purposes.
\end{abstract}

Keywords: solvent, derivatization, parameters, methods, oil
Volume 4 Issue 3 - 2020

\author{
Pedro César Quero-Jiménez,, 13 Lester \\ Alejandro Arias Felipe, ${ }^{2}$ Lisyaulen Rega \\ López $^{3}$ \\ 'Center for Chemical Bioactives, Central University, Cuba \\ 2Department of Bachelor of Chemistry, Central University, Cuba \\ ${ }^{3}$ Ronera Central Agustín, CAl George Washington, Santo \\ Domingo, CP 54830,Villa Clara, Cuba
}

\begin{abstract}
Correspondence: Pedro César Quero-Jiménez, Centro de Bioactivos Químicos, Universidad Central Marta Abreu de Las Villas, Roadto Camajuaní km 5 1/2 Santa Clara, CP 54830,Villa
\end{abstract} Clara, Cuba, Tel +5358507753, Email pquer.jimenez@gmail.com

Received: July 0I, 2020 | Published: September 07, 2020

\section{Introduction}

Within marine species, the shark has resurfaced internationally, not only for the value of its fins, but also for the importance of oil extracted from its liver for health. ${ }^{1}$ The main constituents and nutrients that have been identified in shark liver oil are alkylglycerols, ${ }^{2}$ triglycerides ${ }^{3,4}$ free fattyacids, ${ }^{3}$ fatty acids $\omega-3, \omega-6$ and $\omega-9,{ }^{5}$ vitamin $E$ and $A^{6}$ and squalene. ${ }^{7}$ Shark liver oil is promoted as a dietary supplement used to boost the immune system, fight infection, and heal wounds.

In recent decades, scientists have conducted studies on the positive effects of nutrients available to different marine organisms on health, which may be the key to new treatments for diseases such as cancer ${ }^{8,9}$ neurodegenerative diseases, ${ }^{10}$ human immunodeficiency virus ${ }^{11}$ or cardiovascular disease. ${ }^{12,13}$ In addition, it provides other valuable components such as docosahexaenoic acid (DHA) and eicosapentaenoic acid (EPA), both $\omega-3$, important for optimal neurological development in children, ${ }^{14,15}$ diabetes ${ }^{16}$ and epilepsy. ${ }^{17}$ The recent use of shark liver oil in the development of swine flu vaccines and in certain cosmetic soaps and lotions addstoits invaluable use.

The world production of fish oils reaches millions of tons, of which $88.5 \%$ is destined for aquaculture, and remains are destined to industrial production, human consumption and development of pharmaceutical products and dietary supplements. ${ }^{18,19}$ According Garcia, $2005^{20}$ the low levels of use of fish oil in human nutrition are mainly due to their characteristic odor and taste, as well as the high degree of un saturation of their fatty acids that make them susceptible to oxidation, which has required the application of technological processes that improve their organoleptic properties and guarantee greater stability. These difficulties, together with the need to supplement human nutrition with oils of marine origin, have motivated the food industry to apply procedures that increase the nutritional intake of these fatty acids through the development of functional foods.

The deposit of fat in most cartilaginous fish is located mainly in the liver, some species such as shark and cod accumulate a considerable amount of oil in this organ. ${ }^{21}$ According to the literature it has been reported that the size and weight of the liver in sharks varies depending on the species and time of year and that in some sharks the liver can be up to $20 \%$ of the total weight of the animal..$^{22,23}$ There are different methods for extracting oils from marine species that can be classified into three categories: physical, biological and chemical. ${ }^{24-27}$ Studies carried out express that the application of different extraction methods causes variation in the chemical properties of oils of marine origin. ${ }^{28,29}$

The physical methods of extraction are some of the most used; these include cooking/heating or processing, pressing, drying and grinding. The cooking step is designed to break the fat cells to release oil and press or centrifuge to separate the liquids from the dough. ${ }^{30-33}$ The cooking coagulates the protein, breaks down the fat deposits and releases oil and physicochemical bound water. The cooking step also prepares materials for subsequent operations in several processing units. The coagulation of fish protein occurs at approximately $75^{\circ} \mathrm{C}$, but cooking is typically in the temperature range of $95^{\circ} \mathrm{C}$ to $100{ }^{\circ} \mathrm{C}$ for the duration of (15 to 20) minutes..$^{32}$ Direct and indirect cookers are also used. ${ }^{34}$ The extraction by heat is the most used; ${ }^{35}$ this physical agent favors the release of the oil from the liver cells, at the same time that it inactivates the lipolytic enzymes that cause the hydrolysis of the lipids (reaction that favors the oxidation of the fatty acids). ${ }^{36}$ During the heating process, oxidative processes of the lipids can also be produced; the nature of these alterations depends on factors such as the temperature, the heating time, the degree of unsaturation of the oil, among others ${ }^{37}$ therefore, the objective of this article is to summarize the sample preparation and storage, and the different shark liver oil extraction techniques, based on the basis of the method, and a flash review of the main methods of derivatization of fatty acids is carried.

\section{Preparation and storage}

When sharks are captured, they must be gutted, washed to avoid microbial contamination, placed in polyethylene bags, marked with the date of capture and provenance, then kept in an ice bath at a temperature between $1-5^{\circ} \mathrm{C}$ until fishing boats arrive at the port, ${ }^{20}$ then quickly freeze and store at a temperature below $-18{ }^{\circ} \mathrm{C}$ until use. ${ }^{38-40}$ 
As soon as possible, the livers should be homogenized and removed at the lowest possible temperature, it is recommended not to exceed $20{ }^{\circ} \mathrm{C} .{ }^{39}$ In this circumstance, the main danger is a loss of components of unsaturated fatty acids through the autoxidation of these. Although salt allows for prolonged storage, contact with marine products has been reported to improve oxidation of highly unsaturated lipids directly related to the production of unpleasant tastes and odors, protein denaturation, and texture changes. Therefore, it is clear that the salty dry step involved in the preparation and storage of marine samples could result in oxidized lipids.

All tissues, regardless of their origin, should ideally be removed immediately after removal from the living organism, so that there is little opportunity for changes in lipid components. Of course, it is essential that plasma or tissue samples are taken with the minimum of stress or trauma; otherwise lipolysis will occur in vivo. Lipid peroxidation can also be troublesome in tissues stored at $-20^{\circ} \mathrm{C}$ and even at $-70^{\circ} \mathrm{C}$, and it has been recommended that samples for free radical assays be stored at $-196{ }^{\circ} \mathrm{C} .{ }^{41}$

Enzymatic oxidation has also been shown to cause losses not only of unsaturated fatty acids, but also of intact lipids..$^{42}$ The hydroperoxide groups of the oxidized lipids apparently reacted to form covalent bonds with the membrane proteins, from which they were released only in treatment with bacterial proteases. The different characteristics of the various fatty materials have led to extraction processes as varied as processing, pressing and solvent extraction. However, all extraction processes have certain objects in common. These are, first, to obtain the oil unscathed and as free as possible of undesirable impurities; second, obtain the oil in a performance as high as is consistent with the economy, to produce oil or a residue of the highest possible value.

\section{Extraction methods}

Recent technological advances and the development of new methods to improve production and separation have revolutionized the selection of biomolecules and provided the opportunity to obtain natural extracts that could potentially be used in the manufacture of nutraceutical products. The sin oil extraction processes can be classified into three categories: physical, chemical and biological, but for shark liver oil the most used methods are shown in Table 1.

\section{Physical extraction methods} 2.

The different temperatures of extraction are presented in the Table

\section{Chemical extraction methods}

Solvent extraction involved different methods that discussed in the Table 3.

Table I Most used extraction methods for the analysis of shark liver oil

\begin{tabular}{|c|c|c|c|}
\hline Classification & $\begin{array}{l}\text { Extraction } \\
\text { methods }\end{array}$ & Brief introduction & References \\
\hline Physicists & By temperature & $\begin{array}{l}\text { The basic processing steps involved in shark liver oil extraction include grinding, cooking } \\
\text { / heating or processing, and pressing or centrifuging. The cooking step is designed to } \\
\text { break the fat cells to release oils and press or centrifuge to separate the liquids (water, } \\
\text { soluble protein, and oil) from the dough (solid cake). Cooking coagulates protein, breaks } \\
\text { down fat deposits, and releases oil and physicochemical bound water. }\end{array}$ & 43 \\
\hline Chemicals & $\begin{array}{l}\text { Folch et al.; Bligh } \\
\text { \& Dyer; Mc Gill \& } \\
\text { Moffatt. }\end{array}$ & \multicolumn{2}{|c|}{$\begin{array}{l}\text { Solvent methods in general are an adaptation (in terms of solvent and solvent volumes) of the procedures } \\
\text { of Folch et al., } 1957 \text { and procedures for optimal lipid extraction as reported in the literature. }\end{array}$} \\
\hline & Using soxhlet & $\begin{array}{l}\text { The principle is based on solid-liquid extraction (leaching) and has been the standard } \\
\text { method for more than a century. Nonpolar solvents such as n-hexane, ethyl acetate, } \\
\text { or petroleum ether are used for lipid extraction. Extraction is by repeated washing or } \\
\text { percolation of fresh organic solvent at reflux from a distillation flask. The extraction } \\
\text { efficiency for different classes of compounds depends largely on the properties of the } \\
\text { organic solvent. }\end{array}$ & 43 \\
\hline & $\begin{array}{l}\text { Enzyme-assisted } \\
\text { extraction }\end{array}$ & $\begin{array}{l}\text { The basic principle of enzyme-assisted extraction is that enzymes hydrolyze the cell } \\
\text { and completely break it down under optimal experimental conditions, to release the } \\
\text { intracellular components. Enzymes act on the cell by binding to its active site; this } \\
\text { causes the enzyme to change its shape to fit into the active site of the substrate, causing } \\
\text { maximum interaction between the enzyme and the substrate. The change in the form } \\
\text { of the enzyme leads to the breakdown of the cell wall bonds, thus releasing the active } \\
\text { constituents of the cell wall. The extraction efficiency depends on the temperature } \\
\text { of the system, the mode of action of the enzyme, the duration of the extraction, the } \\
\text { enzyme load, and the availability of the substrate and the pH of the system. }\end{array}$ & 44 \\
\hline
\end{tabular}

Table 2 Temperatures of extraction of shark liver oils discussed by different authors

\begin{tabular}{|c|c|c|c|c|c|}
\hline Species (s) & TAL $\left({ }^{0} \mathrm{C}\right)$ & TE $\left({ }^{0} \mathrm{C}\right)$ & Te (min) & Observations & Reference \\
\hline $\begin{array}{l}\text { Centrophorus squamosus, } \\
\text { Centroscymnus coelolepis, } \\
\text { Centroscyllium fabricii, } \\
\text { Centroscymnus crepidater and } \\
\text { Deania calcea }\end{array}$ & -30 & 70 & - & $\begin{array}{l}\text { They do not analyze the quality or the total } \\
\text { oil extracted, but they refer to the percentage } \\
\text { of extraction of Centroscymnuscoelolepis and } \\
\text { Centrophorussquamosus which is } 77.6 \% \text { and } 77.2 \% \\
\text { respectively. }\end{array}$ & I \\
\hline \multirow[t]{2}{*}{$\begin{array}{l}\text { Ginglimostoma cirratun, } \\
\text { Carcharhinus longimanus and } \\
\text { Carcharhinus falciformes }\end{array}$} & -18 & 70 & 10 & $42.0 \pm 3.8 \%$ extraction yield & 46 \\
\hline & & & & Quality within standard values & \\
\hline
\end{tabular}


Table Continued...

\begin{tabular}{|c|c|c|c|c|c|}
\hline Species (s) & $\operatorname{TAL}\left({ }^{0} \mathbf{C}\right)$ & TE $\left({ }^{0} \mathbf{C}\right)$ & Te (min) & Observations & Reference \\
\hline \multirow[t]{2}{*}{ Squalus acanthias } & -60 & $70-80$ & 30 & $\begin{array}{l}22 \pm 2 \% \text { extraction yield, worse than Bligh and Dyer } \\
\text { and Soxhlet methods. }\end{array}$ & 47 \\
\hline & & & & \multicolumn{2}{|c|}{$\begin{array}{l}\text { Better quality of extraction at } 5{ }^{\circ} \mathrm{C} \text { and excluded from light for up to } \\
3 \text { I days. }\end{array}$} \\
\hline \multirow[t]{2}{*}{ Carcharhinus falciformes } & - & 95 & 30 & $\begin{array}{l}\text { Yield of } 41.7 \pm 0.8 \% \text {, although the Bligh and Dyer } \\
\text { method presents } 63.3 \pm 1.3 \% \text {. }\end{array}$ & 48 \\
\hline & & & & Quality within standard values. & \\
\hline
\end{tabular}

Table 3 Solvent extraction methods

\begin{tabular}{|c|c|c|c|c|}
\hline Method & Species (s) & Solvents & $\begin{array}{l}\text { Storage } \\
\text { temp. }\left({ }^{0} \mathrm{C}\right)\end{array}$ & Reference \\
\hline Folch et al & Echinorhinus brucus & Chloroform and methanol (2: I) & -20 & 40 \\
\hline \multirow[t]{6}{*}{ Bligh and Dyer } & Carcharhinus falciformes & Chloroform, methanol and water & - & 48 \\
\hline & 19 species from Northern Australia & $\begin{array}{l}\text { Chloroform, methanol and water } \\
(2: 1: 0,8)\end{array}$ & -20 & 22 \\
\hline & $\begin{array}{l}\text { Carcharhinus falci form is, Carcharhinus } \\
\text { longimanus, Alopias superciliosus, Prionace } \\
\text { glauca, Sphyrna lewini and Lamna ditropis. }\end{array}$ & $\begin{array}{l}\text { Chloroform, methanol, and water } \\
(2: \text { I: I.8) }\end{array}$ & -20 & 33 \\
\hline & Lamna ditropis & $\begin{array}{l}\text { Chloroform, methanol, and water } \\
(2: \text { I: I.8) }\end{array}$ & -40 & 21 \\
\hline & Squalus acanthias & $\begin{array}{l}\text { Chloroform, methanol, and water } \\
(2: 4: 1)\end{array}$ & -60 & 47 \\
\hline & Galeorhinus galeus and Mustelus antarcticus & $\begin{array}{l}\text { Chloroform, methanol, and water } \\
(1: 2: 0.8)\end{array}$ & -80 & 38 \\
\hline \multirow[t]{2}{*}{$\begin{array}{l}\text { Bligh and Dyer and Mc Gill \& } \\
\text { Moffatt }\end{array}$} & $\begin{array}{l}\text { Carcharhinus falci form is and } \\
\text { Galeocerdocuvier }\end{array}$ & - & -20 & 39 \\
\hline & $\begin{array}{l}\text { Carcharhinus plumbeus, Hexanchus Griseus } \\
\text { and Squalus acanthias }\end{array}$ & Ether & -80 & 49 \\
\hline Soxhlet extraction & Squalus acanthias & Petroleum ether & -60 & 47 \\
\hline
\end{tabular}

\section{Bligh and Dyer method}

This method uses chloroform and methanol (1: $2 \mathrm{v} / \mathrm{v})$, which ensures that for practical purposes the total extraction of lipids from the muscle and that it is reproducible within with a $2 \%$ standard deviation.$^{50}$ This method has been applied and has also been modified by various researchers ${ }^{51-53}$ and it has advantages such as that it is a simple method where the total extraction of lipids is achieved and it is also direct; however, the toxicity of the reagents used means that it is often replaced by other methods. ${ }^{34}$

Castanha et al., ${ }^{54}$ it achieves a total extraction of the lipids of Cryptococcus laurentii, with a high content of fatty acids with 16 and 18 carbon atoms, predominantly oleic, stearic, palmitic, linoleic and lignoceric acids. Aryee \& Simpson, ${ }^{55}$ also makes a comparison of different methods of oil extraction from salmon skin, and shows that by this method and by Folch et al., ${ }^{56}$ the yields are low while the Soxhlet technique with adequate extraction times offers high oil values, however, too long times do not offer better results. Another of the methods used in the comparison was that of Soxtec, which offers a significant reduction in the extraction time and in the volumes of solvents used, obtaining comparable oil contents with the Soxhlet method, it is also shown that approximately 85 are recovered by this \% of solvent used. This method has been widely used ${ }^{57}$ and modifications have been made to improve its performance and extractive processes. ${ }^{51}$ Its use has also been proposed for the solid-liquid extraction of lipids extracted from microorganisms. Meullemiestre et al., ${ }^{58}$ and Breil et al. ${ }^{59,60}$ studying its solvation mechanism, substitution with alternative solvents.

\section{Folch method}

Folch et al., ${ }^{56}$ was one of the first to develop the chloroform/ methanol/water phase system (the so-called "Folch" method); which, under various modifications, continues to be considered the classic and most reliable means of quantitative control for lipid extraction. ${ }^{61}$ According Folch et al., ${ }^{56}$ the only advantage of using the Bligh and Dyer method ${ }^{50}$ is the reduction in the solvent/sample ratio; 1 part tissue to 3 parts in the chloroform/methanol method instead of 1 part tissue to 20 parts chloroform/methanol. This procedure has been widely used ${ }^{62,63}$; Bell et al., ${ }^{64}$ extractedlipids from Atlantics almon (Salmo salar) using the procedure described by Folch, ${ }^{56}$ like wise Gigliotti et al., ${ }^{65}$ reported on lipid extraction from the Atlantic Krill (Euphausia superba), Ramanathan and Das, ${ }^{66}$ also extracted lipids from Scomberomorus commerson using the method described to study the oxidation of lipids from ground fish in the presence of 
antioxidants. This method has also been used for the extraction of lipids from Atlantic mackerel (Scombers combrus), ${ }^{67}$ in the shark species Eusphyra blochii and Carcharhinus bleekeri. ${ }^{68}$

\section{Radin's method}

Due to problems of toxicity by chloroform and removal of more aggressive solvents with health, ${ }^{69}$ proposed a relatively safer organic solvent system, using a hexane-isopropanol solvent system and extracting both the simple lipid classes and the more complex polar lipids bound to cell constituents and membrane proteins. Aryee \& Simpson, ${ }^{55}$ performed a comparison between various salmon oil extraction processes, in which the Radin method produced approximately $32 \%$ salmon oil based on dry weight compared to $35 \%$ of the Bligh and Dyer method ${ }^{50}$ and $43 \%$ of the Folch method. ${ }^{56}$ The low performance of this method has been attributed to the low polarity of isopropanol compared to methanol and the limited efficiency of hexane in the extraction of polar lipids compared to chloroform. ${ }^{70,71}$ According Christie, ${ }^{72}$ extraction solvents or solvent mixtures must be sufficiently polar to eliminate lipid association with other cellular constituents, but must not be very polar so that the solvents do not dissolve all triacylglycerol and other non-polar lipids.

\section{Soxhlet extraction}

This is a simple procedure, which does not require intensive work and also does not use chlorinated solvents, but it has disadvantages since the lipids are not fully extracted, large volumes of solvents are required, special equipment is required and they consume long periods of time. ${ }^{34}$ This method is generally automated in which the solid-liquid extraction is carried out for 90 minutes using apolar solvents such as diethyl ether, hexane, and ethyl acetate, to then carry out a recovery phase for $15 \mathrm{~min}$ and evaporation/drying by another 15 minutes. ${ }^{73}$ However, the relative polarity of chloroform/methanol (2:1 $\mathrm{v} / \mathrm{v})^{56}$ it is higher than that of diethyl ether. Polyunsaturated fatty acids have more polarity, when they have two or more insaturations in their structure, considering that they have a linear form. ${ }^{74}$ Therefore, the Folch method ${ }^{56}$ is more effective than Soxhlet's method for extracting polyunsaturated fatty acids. ${ }^{73}$

A comparison between this method and that of Bligh \& Dyer ${ }^{50}$ to study the contents of fatty acids, especially eicosapentaenoic acid (EPA) and docosahexaenoic acid (DHA) in fats of marine origin, it was carried out by Ozogul et al. ${ }^{28} \mathrm{n}$-heptane and isooctane are used as solvents and you obtain that generally, the differences in the number and volume of fatty acids were much higher in the Soxhlet method with n-heptane and isooctane than Bligh and Dyer method, ${ }^{50}$ although they also observed that when isooctane was used, fatty acid levels decreased, compared to n-heptane, which could be due to heating during the transmethylation procedure, so the use of n-heptane shows to be superior for the recovery of unsaturated fatty acids, especially EPA and DHA. This method has also been integrated into microwave extraction ${ }^{75}$ by means of the use of experimental designs, the central compound was optimized obtaining that at $32 \mathrm{~min}$ the oil obtained was quantitatively and qualitatively (composition of fatty acids) similar to that obtained by conventional Soxhlet for $8 \mathrm{~h}$; furthermore, this is a green technology and appears as a good alternative for the extraction of fats and oils from food products; other authors have also reported the use of this technique. ${ }^{76,77}$

A suitable solvent extraction method can be selected based on a number of criteria. ${ }^{78}$ For example, in a comparative study, ${ }^{79}$ found that the Soxhlet method with methylene chloride: methanol (2:1) is the most selective method for the extraction of neutral lipids, among others. However, the Soxhlet method is not suitable for the extraction of unsaturated lipids due to the instability of these lipids at elevated temperatures during reflux. High temperatures can also accelerate transesterification of lipids in the presence of methanol, changing their natural shape. In this sense, the Bligh and Dyer method ${ }^{50}$ with chloroform and methanol it causes less artifacts, therefore; the results obtained with this method are considerably more reliable and reproducible. ${ }^{79}$ However, the Bligh and Dyer method. ${ }^{50} \mathrm{It}$ is practically not suitable for large-scale extractions due to the high amounts of toxic waste generated, which requires expensive recycling methods and compromises user safety. ${ }^{80}$

\section{Association of official analytical chemists (AOAC) method}

The conventional AOAC method ${ }^{81}$ uses acid digestion to degrade proteins that interact with fatty acids before extraction with petroleum ether/diethyl ether $(1: 1 \mathrm{v} / \mathrm{v})$. Taha et al., ${ }^{82}$ performs a comparison of lipid extraction methods for the determination of fatty acids. Gas chromatographic analysis revealed that total fatty acid recoveries were not statistically different in the methods used $(\mathrm{P}>0.05)$, in this study. This method has also been compared with that of Soxhlet for the determination of fats in bakery products. Shin and Park, ${ }^{83}$ obtaining that the volume of (total) fat extracted by the AOAC 996.06 method was less extracted by the automated Soxhlet and Folch methods ${ }^{56}$ for most samples. In addition, the volumes of saturated fat, monounsaturated fat, and polyunsaturated fat determined by the AOAC 996.06 method. AOAC, ${ }^{81}$ it was also lower than those obtained by Folch ${ }^{56}$ and automated Soxhlet.

\section{Solvent accelerated extraction}

Solvent Accelerated Extraction (EAS) does not require the manual steps involved in preparing samples for analysis, this technique presents increased reproducibility and significant time savings. This procedure was developed for the extraction of aromatic hydrocarbons (PAHs) such as polychlorinated biphenyls (PCBs) and polycyclic ${ }^{34,84}$ It has been used in the isolation of lipids from plants and animal tissue. ${ }^{85}$ EAS provides a flow per system that increases productivity while cost is decreasing, while maintaining automation platform. Although it has the aforementioned advantages, this method does not achieve total lipid extraction, solvent mixtures are required as well as high temperatures and pressures in the system, in addition to the fact that the sample must be dry. ${ }^{34,86}$ EAS has higher extraction power in routine lipid/fatty acid analysis in biological samples. ${ }^{84,87}$

\section{Microwave assisted extraction}

This method uses microwave radiation that causes the movement of the polar molecules and rotation of the dipoles to heat the solvents in contact with the solid matrix and extract the oil volumes, ${ }^{25}$ in recent years it has been widely developed due to a series of factors such as the reduction of extraction time and the consumption of solvents, it can be automated ${ }^{34}$ a greater penetration of the solvent in the cellular tissues that causes a higher yield, higher extraction rates at low temperatures, ${ }^{88,89}$ in addition to offering the possibility of simultaneously drawing different types of samples. ${ }^{88}$ However, it has disadvantages such as high energy consumption, heating affects only polar solvents and/or materials, difficult technological scaling, as a result of heat generation, the oxidation of unsaturated fatty acids can be caused and the use of volatile solvents causes low efficacy. ${ }^{5,90-93}$ By means of this extraction, high oleic acid values are obtained, according to a comparison of different lipid extraction methods in Botalo coccus sp. ${ }^{94}$ 


\section{Extractionby supercritical fluids (SCFE)}

Supercritical fluids extraction has received increasing attention as an alternative to conventional extraction methods. ${ }^{95}$ Not only is there a significant reduction in the use of organic solvents, but waste concerns are also avoided. Although the time reduction is not as great as in some microwave procedures, SCFE has gained much wider acceptance. Potentially causes fewer adverse conditions for fatty acids due to the low temperature of the extracting fluid, usually supercritical carbon dioxide $\left(\mathrm{S}-\mathrm{CO}_{2}\right)$. Extractions using only $\mathrm{S}-\mathrm{CO}_{2}$ generally produce good recoveries of nonpolar lipids. ${ }^{96}$ However, polar lipids may remain unextracted due to their lower solubility in $\mathrm{S}-\mathrm{CO}_{2}$, and therefore samples containing a certain amount of these types of lipids (eg milk) may present extraction difficulties. To improve the extraction of non-polar lipids, the polarity of $\mathrm{S}_{-} \mathrm{CO}_{2}$ can be varied using solvents such as methanol, ethanol or even water. Several researchers have reported that the solubility of lipids in $\mathrm{S}-\mathrm{CO}_{2}$ is greatly increased by adding ethanol, and some phospholipids are extracted at levels directly proportional to the added ethanol. ${ }^{6,97}$

The presence of dissolved water in the supercritical the fluid also increases the solubility of polar compounds, and has been used successfully to analyze various dairy products. ${ }^{98}$ Sample preparation should also be considered. Particle size affects lipid recovery by influencing the surface area of the exposed sample to $\mathrm{S}-\mathrm{CO}_{2}{ }^{85}$ The moisture content of the samples also affects the extraction efficiency by conditioning the surface structure. ${ }^{99}$ The high moisture content reduces the contact of the $\mathrm{S}-\mathrm{CO}_{2}$ sample due to the pasty consistency of the samples, and the moisture acts as a barrier to the diffusion of $\mathrm{S}-\mathrm{CO}_{2}$ in the sample, as well as the diffusion of lipids out of the sample. ${ }^{100}$ In this way, an increase in lipid recovery with lower moisture content has been demonstrated in wet samples such as meat ${ }^{101}$ and fish, ${ }^{102}$ although humidity does not affect the extraction capacity in a low content. ${ }^{102,103}$ Therefore, samples with a high moisture content are usually lyophilized prior to $\mathrm{S}-\mathrm{CO}_{2}$ extraction to improve efficiency. ${ }^{101-104}$

This method offers advantages such as being fast, does not require the use of toxic solvents and the extractshave a high purity, free of heavy metals and inorganic salts, there is also no presence of polar substances that can form polymers, and low temperatures of extraction $\left(40-80^{\circ} \mathrm{C}\right)$. However, the equipment is expensive, and complex since it has to work at high pressures, high purity $\mathrm{CO}_{2}$ must be used and it needs large amounts of energy for its use. . $5,34,97,105^{2}$

\section{Ultrasonic extraction}

This method uses ultrasound to penetrate the solvents in contact with the solid matrix to extract the contents of the sample in solution. It presents advances with respect to other techniques such as the shorter extraction time and solvent consumption, high penetration of the solvent into the cellular material, which causes it to release its content into the medium, although these represent clear advances, its difficult scalding at an industrial level and the high energy consumption make this technique still little used.Ultrasonic assisted solvent extraction has also been used for accelerated extraction of phenolic compounds from plant matrices. This process is considered effective compared to other conventional extraction methods, as it allows cell disruption to allow interactions of phenolic molecules with solvents at a reasonably low temperature. ${ }^{89}$

UAE significantly reduces extraction time and increases extraction yields of many natural matrices, due to the production of cavitation bubbles in the solvent. ${ }^{106}$ Cavitation bubbles are produced in the liquid during the expansion phase. The negative pressure exerted by the expansion cycle exceeds the local tensile strength of the liquid. ${ }^{107,108}$ This ability to cause cavitation depends on the characteristics of the ultrasound wave, the properties of the solvent, and the environmental conditions. ${ }^{108,109}$ After a cavitation bubble is produced, it collapses during the compression cycle, which pushes the liquid molecules together, and a high-speed micro-jet is created toward the matrix particle, promoting mixing of the solvent with the matrix. The high pressure and temperature involved in this process, which can reach up to $1000 \mathrm{bar}$ and up to $4726.85^{\circ} \mathrm{C}$, respectively, are responsible for the increase in mass transfer, since the shock wave breaks cell walls and membranes. ${ }^{108,109}$ After cell disruption, the solvent can easily penetrate the solid particle, releasing the intracellular compounds to the bulk solvent. ${ }^{109-112}$

The application of ultrasound can be divided into two different categories: low intensity-high frequency ultrasound $(100 \mathrm{kHz}-1$ $\mathrm{MHz}$ ) and high intensity-low frequency (between 20 and $100 \mathrm{kHz}$ ), the latter being the only case that leads to disruption of cell walls and membranes ${ }^{109-114}$ More recent studies have shown that ultrasonic assisted extraction using acoustic cavitation and mechanical impact can improve extraction efficiency. Acoustic cavitation can break the cell wall facilitating the penetration of the solvent into the plant material and allowing the cell to release the product. The ultrasonic mechanical impact offers a greater penetration of solvents into the sample matrix because it increases the contact area between the solvent and the extractable compounds. UAE requires less extraction time and less solvent consumption and can be carried out at low temperatures, which can reduce damage caused by temperature and minimize the loss of bioactive substances..$^{25,115}$

Abdullah et al., ${ }^{116}$ they used UAE in ethanol to extract the oil from the Monopterusalbus fillets. Before extraction, the material had to be dried $\left(60{ }^{\circ} \mathrm{C}\right)$ and homogenized in a blender. The optimal extraction parameters are $25 \mathrm{kHz}, 200 \mathrm{~W}, 25 \mathrm{kHz}, 200 \mathrm{~W}, 60 \mathrm{~min}$ of sonication time and $500 \mathrm{ml}$ of ethanol. Final production - 7.2\% of dry fillet material. In another job, Xiao et al., ${ }^{117}$ extracted $94.82 \%$ of the total lipids using cyclohexane medium, optimal extraction parameters liquid/solid ratio of $4: 1$ to $50{ }^{\circ} \mathrm{C}$ in $57 \mathrm{~min}$ and $400 \mathrm{~W}$ of extraction power. Khoei \& Chekin, ${ }^{118}$ performed a comparison of this method with the Soxhlet extraction and the results showed that the oil performance in the aqueous extraction assisted by ultrasound was close to the performance of the oil extracted with hexane by Soxhlet, which implies that the performance was significantly influenced by ultrasound . Regarding quality, the oil extracted by an ultrasoundassisted aqueous process had a lower content of free fatty acids and pigments than that extracted in hexane.

\section{Other extraction methods}

Gigliotti et al., ${ }^{65}$ proposes an extraction method that uses a solvent system, acetone-ethanol $(1: 1, \mathrm{v} / \mathrm{v})$, which is compared to the Folch method, ${ }^{56}$ Soxhlet, ${ }^{119}$ and conventional two-stage extraction, ${ }^{120,121}$ in Euphausiasuperba. This study demonstrated that the proposed method produced the highest yield efficiency, with phospholipids being the main compounds in the oil obtained, while this also contains $\omega-3$ such as EPA and DHA. In addition, the extracted oil had low cholesterol contents and a high antioxidant capacity compared to other treatments.

Ghaly \& Ramakrishnan, ${ }^{122}$ an enzymatic extraction method was used in which the enzyme alcalase was used at three concentrations 
of the enzyme $(0.5,1$ and $2 \%)$ and four time intervals $(1,2,3$ and 4 h). The oil obtained after enzymatic hydrolysis was dark due to the formation of pigments resulting from the reaction of carbonyls of the oxidation of polyunsaturated AGs with amino acids and proteins. The highest oil yield $(76.26 \%$ of the head and $75.71 \%$ of the whole fish) was obtained using $2.0 \%$ concentration of the enzyme after $4 \mathrm{~h}$ of hydrolysis. In summary, these methods have advantages such as the non-use of organic solvents and the low cost of protease enzymes, as well as the disadvantage of being difficult to scale technologically. ${ }^{25}$

\section{Main derivatization method used}

HCl-Methanol: This method is described by Antolín et al., ${ }^{123}$ which makes a comparison between different derivatization methods, this being the most time consuming, around 90 minutes to complete the process, while the other methods only require 10 minutes. This method has been used by several authors. ${ }^{124}$

Martins et al., ${ }^{124}$ makes a comparison between this method and the one that uses $\mathrm{Bf} 3 / \mathrm{MeOH}$, to later determine the fatty acids by $\mathrm{GC}$ in three species of Brazilian algae. When comparing the fatty acid contents in the species; when the transesterification was performed by the $\mathrm{B} \& \mathrm{D}-\mathrm{BF}_{3}$ method, S. cymosum and $\mathrm{H}$. musciformis showed the highest and lowest fatty acid contents, respectively. S. cymosum also showed higher concentrations of palmitoleic, oleic and arachidonic acid methyl esters when using the B\&D-Bf3 method. However, when the AOM-HCl method was used, H. musciformis showed higher concentrations of palmitic, myristic and arachidonic methyl esters than the other species and significant differences between palmitoleic and oleic acid species. The fatty acid contents of the three species of seaweed were significantly different when they were extracted and transesterified by the different methods. Furthermore, the best method for one species was not the same for the others, which points to a matrix effect and that the method used for the analysis of the fatty acid content of different organisms must be carefully selected. Tang et al., ${ }^{125}$ performs an optimization of the method for the determination of fatty acids in Nannochloro psisgaditana. Total yields of methylated fatty acids and EPA were 1.58 and 1.23 times higher separately than those obtained by the conventional two-step method (solvent system: methanol and chloroform). This one-step, on-site method is quick and simple for measuring fatty acid methyl ester yields and could serve as a promising method for generating EPA methyl esters from microalgae. This method has also been used by Meier et al., ${ }^{126}$ in which a one-step extraction/methylation procedure is validated.

$\mathbf{H}_{2} \mathbf{S O}_{4}-$ Methanol: According Antolín et al., ${ }^{123}$ the cost, speed, safety and response by gas chromatographic, of the method that uses sulfuric acid-methanol $\left(\mathrm{H}_{2} \mathrm{SO}_{4}-\mathrm{MeOH}\right)$ as a deriving agent turned out to be the most appropriate to determine fatty acids. Validation of this method demonstrated: linearity in a range $40-160 \%$, accuracy was assessed through a recovery study, day-to-day and day-to-day precision, and specificity. Gu et al., ${ }^{127}$ although it does not use the method described by Christie, ${ }^{128}$ in which the methylation and hydrolysis of lipids occurs in a single stage, by adding $700 \mu \mathrm{L}$ of methanol with $2.5 \% \mathrm{H}_{2} \mathrm{SO}_{4}$ and homogenizing it for $1 \mathrm{~min}$, and then incubating it at $80^{\circ} \mathrm{C}$ for 90 min and practicing several extractions successive with $n$-hexane. The procedure has also been described by Figueiredo et al. ${ }^{129}$

$\mathbf{B F}_{3}-$ Methanol: This method has been described by different authors. Antolín et al., ${ }^{123}$ Moss et al., ${ }^{130}$ and Ackman, ${ }^{131}$ performs a review of the official methods that $\mathrm{BF}_{3}$ is used for the preparation of fatty acid methyl esters. Zhang et al., ${ }^{132}$ makes a comparison between the conventional method that uses $\mathrm{KOH}-\mathrm{MeOH}$ according to ISO 12966-2, ${ }^{133}$ with some modifications and the method using $\mathrm{BF}_{3}-\mathrm{MeOH},{ }^{134}$ also with some modifications; in vegetable oil matrices. Lewis acid $\mathrm{BF}_{3}$ forms a coordination complex with methanol, a powerful catalyst for the esterification of fatty acids. But the result of this study showed that the level of fatty acid esterification was very low, the chromatographic peaks were not identified and the composition of the isomers also changed when the $\mathrm{BF}_{3} / \mathrm{MeOH}$ method was carried out. It should be noted that the reaction temperature is usually $100^{\circ} \mathrm{C}$ (the boiling point of $\mathrm{MeOH}$ was $60{ }^{\circ} \mathrm{C}$ ), so high temperatures can cause solvent loss and as a consequence the reaction cannot be completed, in addition to there may be transfer of double bonds. Methoxides were produced from the unsaturated fatty acids by the addition of methanol to the double bond even when normal concentrations of $\mathrm{BF}_{3} / \mathrm{MeOH}$ were used (not more than 50\%), so this is not a reliable catalyst resulting in many unwanted products. ${ }^{135}$ Side reactions have also been reported to be increased by the presence of oxidized lipids, and sample size is also critical with substantial losses sometimes occurring with samples less than $200 \mathrm{mg} .{ }^{136}$ The risk of side reactions increases with longer reaction times, so $\mathrm{BF}_{3} / \mathrm{MeOH}$ has serious disadvantages, if it is also considered that this reagent is expensive and not stable, although it is refrigerated compared to $\mathrm{KOH}$ which is stable during several months at low temperatures. ${ }^{123,132}$ Compared to the $\mathrm{BF}_{3} / \mathrm{MeOH}$ method, with the $\mathrm{KOH} / \mathrm{MeOH}$ method the latter is more effective, simpler, less laborious, and easier to handle. ${ }^{132}$ According to Martins et al., ${ }^{124}$ this method produces false results due to the high matrix effect it presents.

NaOH-Methanol: Guil-Guerrero et al., ${ }^{137}$ used a method in which the fish oil samples were mixed with a solution of methanol and acetyl chloride (20: 1, v/v) and $20 \mathrm{~mL}$ of hexane, previously described by Rodríguez-Ruiz et al. ${ }^{138}$ An alternative to this method is a mixture of $\mathrm{NaOH}-m e t h a n o l$ and hexane, for the preparation of the methyl esters, however the $\mathrm{BF}_{3} / \mathrm{MeOHreagent}$ is used as a catalyst, ${ }^{139}$ although this procedure has been used by several authors. ${ }^{140,141}$ Figueiredo et al. ${ }^{129}$ proposes and compares a new method of transesterification with conventional methods and widely described in the literature. ${ }^{142}$ In this, $2 \mathrm{~mL}$ of sodium hydroxide $(\mathrm{NaOH})\left(1.5 \mathrm{~mol} . \mathrm{L}^{-1}\right.$ in methanol) are added to the samples, to then be placed in an ultrasonic bath. After the alkaline reaction described above, $2 \mathrm{~mL}$ of $\mathrm{H}_{2} \mathrm{SO}_{4}$ or $\mathrm{HCl}(1.5 \mathrm{~mol}$. $\mathrm{L}^{-1}$ in methanol for both cases), to be placed again in the ultrasonic bath for a time simultaneously studied by means of an experimental design. I know that $\mathrm{H}_{2} \mathrm{SO}_{4}$ was more effective than $\mathrm{HCl} .{ }^{129}$ GuilGuerrero et al., ${ }^{143}$ using this method for the simultaneous extraction and saponification of Isurus oxyrinchus liver oil, this method was optimized by means of an experimental design.

Other methods: These procedures, although less described in the literature, have been developed and discussed in important investigations. Xu et al., ${ }^{144}$ compares three methods that use methanol/ benzene $(4: 1, \mathrm{v} / \mathrm{v})$ and then $200 \mu \mathrm{L}$ of acetyl chloride are added to proceed with the transesterification for $1 \mathrm{~h}$ at $100^{\circ} \mathrm{C}$. One-stage digestion, extract and sample esterification is known as 'direct transesterification' and is widely used due to its simplicity, speed and high accuracy. ${ }^{145-147}$ This method presents some complications, such as: the addition of acetyl chloride generates an exothermic reaction that sometimes results in sample loss and possible injury to the analyst; adding acetyl chloride slowly and with stirring is difficult for large numbers of samples; in addition, certain polyunsaturated fatty acids are not very stable at $100^{\circ} \mathrm{C}$ during the transesterification process; and the generation of molecular species that can contribute to fatty acids degradation. ${ }^{148}$ This method has also been used by GuilGuerrero et al., ${ }^{143}$ and Masoodet al. ${ }^{147}$ 
Tang et al., ${ }^{125}$ optimizes a transesterification process in situ for the quantification of EPA in Nannochloropsis gaditana. This method was previously described by Laurens et al., ${ }^{149}$ and it provides advantages over the conventional two-stage method, such as speed, which is simple and reliable. Laffargue et al. ${ }^{150}$ describes a method described in the literature and which has been widely described in studies of plant physiology ${ }^{151,152}$ in which the fatty acids are separated by thin layer chromatography. The researchers use an alternative method consisting of the selective derivatization of fatty acids without their previous purification, which uses diazomethane that is ineffective for transmethylation of fatty acids. Diazomethane is potentially explosive, it is only stable for very short periods and has to be prepared on site, in addition to being carcinogenic. ${ }^{153}$ A method using diethoxymethaneassisted methanol is described by Zeng et al., ${ }^{154}$ which offers advantages such as shorter reaction time, and also requires small amounts of the catalyst and methanol. Another versatile technique for the derivatization of fatty acids is ultrasound irradiation, which has been compared to classical methylation. ${ }^{135}$

\section{Conclusions}

According to the estimates of the present study it is suggested that different methods could be used to extract oil for food and feed purposes. The method to be used for the extraction depends on several factors, among which its cost and the materials to be used stand out. This work has reviewed well-known and widely practiced methods of oil extraction namely and conventional methods (solvent extraction), as well as new innovative methods aimed at raising and optimizing oil yield and improving oil quality. The main derivatization methods are also reviewed since among edible oils the determination of fatty acids is one of the quality parameters most studied and disseminated in the scientific literature. Major shortcomings associated with the conventional methods are solvent consumption, extraction time lag and adverse thermal effects at high temperatures that can produce oxidative processes of lipids. New techniques such as microwaveassisted extraction, ultrasonic-assisted extraction, and supercritical fluid extraction have been developed, and are being used to effectively reduce these shortcomings. The most suitable process based on cost, environmental friendliness, and oil yieldnot is specified because depend of factors such as the conditions of the laboratory, the level of development of the industry and the objective of the research. Although, as previously stated, the researchers apply the most feasible, least-cost method that suits their research purposes.

\section{Acknowledgments}

None.

\section{Conflicts of interest}

Authors declare that there are no conflicts of interest.

\section{Funding}

None.

\section{References}

1. H Kjerstad, I Fossen, MH Willemsen. Utilization of deep-sea sharks at Hatton Bank in the North Atlantic. Journal of Northwest Atlantic Fishery Science. 2003;31:333-338.

2. L Vázquez, T Fornari, FJL Señoráns, et al. Supercritical carbon dioxide fractionation of nonesterified alkoxyglycerols obtained from shark liver oil. Journal of Agricultural and Food Chemistry. 2008;56(3):1078-1083.
3. ZS Saify, S Akhtar, KM Khan, et al. A study on the fatty acid composition of fish liver oil from two marine fish. Turkish Journal of Chemistry. 2003;27:251-258.

4. C Jayasinghe, N Gotoh, S Wada. Regiospecific analysis of shark liver triacylglycerols. Journal of the American Oil Chemists Society.2012;89(10):1873-1884.

5. L Wang, CL Weller. Recent advances in extraction of nutraceuticals from plants. Trends in Food Science \& Technology. 2006;17(6):300-312.

6. O Catchpole, J Grey, K Noermark, K. Fractionation of fish oils using supercritical $\mathrm{CO}_{2}$ and $\mathrm{CO}_{2}+$ ethanol mixtures. The Journal of Supercritical Fluids. 2000;19(1):25-37.

7. T Rosales-Garcia, C Jimenez-Martinez, G Davila-Ortiz. Squalene Extraction:Biological Sources and Extraction Methods. International Journal of Environment, Agriculture and Biotechnology. 2017;2(4):16621670.

8. M Correia, E Sousa, MM Pinto, et al. Anticancer and cancer preventive compounds from edible marine organisms. Seminars in Cancer Biology. 2017;46:55-64.

9. M Gómez, JM Laparra, V Loria-Kohen, et al. Tolerability and safety of a nutritional supplement with potential as adjuvant in colorectal cancer therapy:A randomized trial in healthy volunteers. Nutrients. 2019;11(9):2001

10. R Gopal, M Vijayakumaran, $R$ Venkatesan, et al. Marine organisms in Indian medicine and their future prospects. Indian Journal of Natural Products and Resources.2008;7(2):139-145.

11. F Güneş. Medical use of squalene as a natural antioxidant. Journal of Marmara University Institute of Health Sciences. 2013:1.

12. JL Fidalgo, P Dynarowicz-Latka, J Miñones. Effects of saturated and polyunsaturated fatty acids on interactions with cholesterol versus 7-ketocholesterol in Langmuir monolayers and their potential biological implications. Colloids and Surfaces B: Biointerfaces. 2019;174:189-198.

13. MM Norde, E Oki, MM Rogero. C-reactive protein and fatty acids.In The Molecular Nutrition of Fats. Elsevier. 2019. p. 117-133.

14. SS Al-Ghannami, S Al-Adawi, K Ghebremeskel, et al. Randomized open-label trial of docosahexaenoic acid-enriched fish oil and fish meal on cognitive and behavioral functioning in Omani children. Nutrition. 2019;57:167-172.

15. MS Coelho, SS Fernandes, MM Salas-Mellado. Association between diet, health, and the presence of bioactive compounds in foods. In Bioactive Compounds. Elsevier. 2019:159-183.

16. T Behl, $\mathrm{M}$ Grover, $\mathrm{K}$ Shah. Role of Omega-3-fatty acids in the management of diabetes and associated complications. In: Bioactive Food as Dietary Interventions for Diabetes. Elsevier. 2019:185-192.

17. S Tejada, M Martorell, X Capó, et al. Omega-3 fatty acids and epilepsy. In: The Molecular Nutrition of Fats. Elsevier. 2019:261-270.

18. AGJ Tacon, M Metian.Global overview on the use of fish meal and fish oil in industrially compounded aquafeeds:Trends and future prospects. Aquaculture. 2008;285(1-4):146-158.

19. V Rizliya, E Mendis. Biological, physical, and chemical properties of fish oil and industrial applications. In: Seafood processing by-products. New York, NY: Springer New York; 2014:285-313.

20. E García. Use of shark liver oil obtained in Cuba in the development of nutritionally improved products. 2005.

21. C Jayasinghe, N Gotoh, S Tokairin, et al. Inter species changes of lipid compositions in liver of shallow-water sharks from the Indian Ocean. Fisheries Science. 2003;69(3):644-653. 
22. PD Nichols, M Rayner, J Stevens. FRDC Project Report 99/369. In A pilot investigation on Northern Australian shark liver oils: Characterization and value-adding. Australia: CSIRO Marine Research and Fisheries Research and Development Corporation; 2001.

23. M Kohlmeier. Fatty Acids. In: Nutrient Metabolism. Elsevier. 2015; p. 111-186.

24. P Jayasinghe, I Adeoti, K Hawboldt. A study of process optimization of extraction of oil from fish waste for use as a low-grade fuel. Journal of the American Oil Chemists'Society. 2013;90(12):1903-1915.

25. K Ivanovs, D Blumberga. Extraction of fish oil using green extraction methods:a short review. Energy Procedia. 2017;128:477-483.

26. SS Nadar, P Rao, VK Rathod. Enzyme assisted extraction of biomolecules as an approach to novel extraction technology: A review. Food Research International. 2018;108:309-330.

27. C Wen, J Zhang, H Zhang, et al. Advances in ultrasound assisted extraction of bioactive compounds from cash crops - A review. Ultrasonics Sonochemistry. 2018;48:538-549.

28. Y Ozogul, A Șimșek, E BalIkçI, et al.The effects of extraction method on the contents of fatty acids, especially EPA and DHA in marine lipids. International Journal of Food Sciences and Nutrition. 2012;63(3):326331.

29. D Fiorini, R Gagliardi, A Petrini, et al. Comparison of eleven extraction methods for quantitative evaluation of total lipids and fatty acids in the clam Anadara Inaequivalvis (Bruguière). Journal of Shellfish Research. 2013;32(2):285-290.

30. F Shahidi. Bailey's Industrial Oil and Fat Products. Hoboken, NJ, USA John Wiley \& Sons Inc; 2005.

31. AGJ Tacon, MR Hasan, RP Subasinghe. Use of Fishery Resourse as Feed Inpouts to Aquaculture Development: Trends and Policy Implications. Rome: FAO; 2006.

32. M Aursand, R Mozuraityte, K Hamre, et al. Description of the processes in the value chain and risk assessment of decomposition substances and oxidation products in fish Oils. Opinion of Steering Committee of the Norwegian Scientific Committee for Food Safety. Norway: NTNU; 2011.

33. P Jayasinghe, K Hawboldt. A review of bio-oils from waste biomass:Focus on fish processing waste. Renewable and Sustainable Energy Reviews.2012;16(1):798-821.

34. IA Adeoti, K Hawboldt. A review of lipid extraction from fish processing by-product for use as a biofuel. Biomass and Bioenergy. 2014;63:330 340 .

35. I Aidos, Avan der Padt, RM Boom, et al. Upgrading of maatjes herring byproducts:production of crude fish oil. Journal of Agricultural and Food Chemistry. 2001;49(8):3697-3704.

36. MD Guillén, A Ruiz, N Cabo. Study of the oxidative degradation of farmed salmon lipids by means of Fourier transform infrared spectroscopy. Influence of salting. Journal of the Science of Food and Agriculture. 2004;84(12):1528-1534.

37. B Muik, B Lendl, A Molina-Díaz, et al. Direct monitoring of lipid oxidation in edible oils by Fourier transform Raman spectroscopy. Chemistry and Physics of Lipids. 2005;134(2):173-182.

38. PD Nichols, MJ Bakes, NG Elliott. Oils rich in docosahexaenoic acid in livers of sharks from temperate Australian waters. Marine and Freshwater Research. 1998;49(7):763.

39. G Navarro, R Pacheco-Aguilar, B Vallejo-Cordova, et al. Lipid composition of the liver oil of shark species from the Caribbean and Gulf of California Waters. Journal of Food Composition and Analysis. 2000;13(5):791-798
40. V Venugopal, AK Kumaran, N Sekhar, et al. Biochemical characterization of liver oil of Echinorhinus brucus (Bramble Shark) and its cytotoxic evaluation on neuroblastoma cell lines (SHSY-5Y). Scientifica. 2016:1-6.

41. M Shabihkhani, GM Lucey, B Wei, et al. The procurement, storage, and quality assurance of frozen blood and tissue biospecimens in pathology, biorepository, and biobank settings. Clinical Biochemistry.2014;47(4-5):258-266.

42. M Chavez-Gonzalez, JJ Buenrostro-Figueroa, CN Aguilar. Handbook of Research on Food Science and Technology. Vol 1. UK: Apple Academic Press; 2019

43. I Adetunji. Extraction of oil from fish processing waste for fuel applications:Process development, analysis and feasibility. Memorial University of Newfoundland. 2015.

44. PW Mwaurah, S Kumar, NP Kumar, et al. Novel oil extraction technologies:Process conditions, quality parameters, and optimization. Comprehensive Reviews in Food Science and Food Safety. 2020;19(1):320

45. J Liu, MA Gasmalla, P Li, et al. Enzyme-assisted extraction processing from oilseeds:Principle, processing and application. Innovative Food Science \& Emerging Technologies. 2016;35:184-193.

46. E García, S Gutiérrez, H Nolasco, et al. Lipid composition of shark liver oil:effects of emulsifying and microencapsulation processes. European Food Research and Technology. 2006;222(5-6):697-701.

47. S Hole, M Hole, KDA Taylor. Methods of extraction composition and stability of vitamin A and other components in dogfish (Squalus acanthias) liver oil. Food Chemistry. 1996;55(3):215-220.

48. C Jayasinghe, WMK Perera, A Bamunuarachchi. Influence of extraction methods on quality of shark liver oils. Sri Lanka: Asia-Pacific Fishery Commission, Food and Agriculture Organization of the United Nations; 1998

49. BM Wetherbee, PD Nichols. Lipid composition of the liver oil of deep-sea sharks from the Chatham Rise, New Zealand. Comparative Biochemistry and Physiology Part B: Biochemistry and Molecular Biology. 2000;125(4):511-521.

50. E Bligh, WJ Dyer. A rapid method of total lipid extraction and purification. J Biochem Physiol.1959;37:911-917.

51. JE Kinsella, JL Shimp, J Mai, et al. Fatty acid content and composition of freshwater finfish. Journal of the American Oil Chemists' Society. 1977;54(10):424-429.

52. A Amuamuta, Z Mekonnen, A Agazie. Extraction and analysis of oil/ fat and fatty acids content from different indigenous fish of Lake Tana source, Northwest Ethiopia. World Journal of Fish and Marine Sciences. 2014;6(5):417-423.

53. A Özyılmaz, AÖksüz. Determination of the biochemical properties of liver oil from selected cartilaginous fish living in the northeastern mediterranean. Journal of Animal and Plant Sciences. 2015;25(1):160 167.

54. RF Castanha, LA Salgado de Morais, A Pinto Mariano, et al. Comparison of two lipid extraction methods produced by yeast in cheese whey. Brazilian Archives of Biology and Technology. 2013;56(4):629-636.

55. ANA Aryee, BK Simpson. Comparative studies on the yield and quality of solvent-extracted oil from salmon skin. Journal of Food Engineering. 2009;92(3):353-358.

56. J Folch, M Lees, GH Sloane Stanley. A simple method for the isolation and purification of total lipides from animal tissues. The Journal of biological chemistry. 1975;226(1):497-509.

57. LS Inouye, GR Lotufo. Comparison of macro-gravimetric and microcolorimetric lipid determination methods. Talanta. 2006;70(3):584-587. 
58. A Meullemiestre, C Breil, M Abert-Vian, et al. Modern techniques and solvents for the extraction of microbial oils. Cham:Springer International Publishing (SpringerBriefs in Molecular Science). 2015.

59. C Breil, A Meullemiestre, M Albert Vian, et al. Bio-based solvents for green extraction of lipids from oleaginous yeast biomass for sustainable aviation biofuel. Molecules. 2016;21(2):196.

60. C Breil, M Abert Vian, T Zemb, et al. "Bligh and Dyer" and Folch Methods for solid-liquid-liquid extraction of lipids from microorganisms. Comprehension of solvatation mechanisms and towards substitution with alternative solvents.International Journal of Molecular Sciences. 2017;18(4):708.

61. SJ Iverson, SLC Lang, MH Cooper. Comparison of the bligh and dyer and folch methods for total lipid determination in a broad range of marine tissue. Lipids. 2001;36(11):1283-1287.

62. A Caligiani, A Marseglia, A Sorci, et al.Influence of the killing method of the black soldier fly on its lipid composition. Food Research International. 2019;116:276-282.

63. F Sardenne, N Bodin, L Metral, et al. Effects of extraction method and storage of dry tissue on marine lipids and fatty acids. Analytica Chimica Acta. 2019;1051:82-93.

64. JG Bell, F McGhee, PJ Campbell, et al. Rapeseed oil as an alternative to marine fish oil in diets of post-smolt Atlantic salmon (Salmo salar):changes in flesh fatty acid composition and effectiveness of subsequent fish oil "wash out". Aquaculture. 2003;218(1-4):515-528.

65. JC Gigliotti, MP Davenport, SK Beamer, et al. Extraction and characterisation of lipids from Antarctic krill (Euphausia superba). Food Chemistry. 2011;125(3):1028-1036.

66. L Ramanathan, NP Das. Studies on the control of lipid oxidation in ground fish by some polyphenolic natural products. Journal of Agricultural and Food Chemistry.1992;40(1):17-21.

67. M Bernárdez, L Pastoriza, G Sampedro, et al. Modified method for the analysis of free fatty acids in fish. Journal of Agricultural and Food Chemistry. 2005;53(6):1903-1906.

68. ZS Saify, S Akhtar, S Hassan, et al. A study on fatty acid composition of fish oil from two marine fish, Eusphyra blochii and Carcharhinus bleekeri. PakJ Pharm Sci.2000;13(2):5-12.

69. NS Radin. Extraction of tissue lipids with a solvent of low toxicity. Methods in Enzymology. 1981;72:5-7.

70. H Gunnlaugsdottir, RG Ackman. Three extraction methods for determination of lipids in fish meal:Evaluation of a hexane/isopropanol method as an alternative to chloroform-based methods. Journal of the Science of Food and Agriculture. 1993;61(2):235-240.

71. I Undeland, M Härröd, H Lingnert. Comparison between methods using low-toxicity solvents for the extraction of lipids from herring (Clupea harengus). Food Chemistry.1998;61(3):355-365.

72. WW Christie. Preparation of fatty acid methyl esters. Inform. 1992;3(9):1031-1034.

73. JM Shin, YO Hwang, OJ Tu, et al. Comparison of different methods to quantify fat classes in bakery products. Food Chemistry. 2013;136(2):703709.

74. BS Ghotra, SD Dyal, SS Narine. Lipid shortenings:a review. Food Research International. 2002;35(10):1015-1048.

75. M Virot, V Tomao, G Colnagui,et al. New microwave-integrated Soxhlet extraction. Journal of Chromatography A. 2007;1174(1-2):138-144.

76. J Luque Garcia, MD Luque de Castro. Focused microwave-assisted Soxhlet extraction:devices and applications. Talanta. 2004;64(3):571577.
77. MD Luque de Castro, F Priego-Capote. Soxhlet extraction:Past and present panacea. Journal of Chromatography A. 2010;1217(16):23832389.

78. M Onay, C Sonmez, HA Oktem, et al. Evaluation of various extraction techniques for efficient lipid recovery from thermo-resistant microalgae. American Journal of Analytical Chemistry. 2016;7(2):141-150.

79. JB Guckert, KE Cooksey, LL Jackson. Lipid sovent systems are not equivalent for analysis of lipid classes in the microeukaryotic green alga, Chlorella.Journal of Microbiological Methods. 1988;8(3):139-149.

80. F Sahena, ISM Zaidul, S Jinap, et al. Application of supercritical $\mathrm{CO}_{2}$ in lipid extraction - A review. Journal of Food Engineering. 2009;95(2):240 253.

81. AOAC. Official Method 996.06: Fat (Total, Saturated, and Unsaturated) In AOAC Official Methods of Analysis. 18th edn. Gaithersburg. 2005.

82. AY Taha, AH Metherel, KD Stark. Comparative analysis of standardised and common modifications of methods for lipid extraction for the determination of fatty acids. Food Chemistry. 2012;134(1):427-433.

83. JM Shin, SK Park. Comparison of fat determination methods depending on fat definition in bakery products. LWT - Food Science and Technology. 2015;63(2):972-977.

84. SJ Macnaughton, TL Jenkins, MH Wimpee, et al. Rapid extraction of lipid biomarkers from pure culture and environmental samples using pressurized accelerated hot solvent extraction. Journal of Microbiological Methods. 1997;31(1-2):19-27.

85. ED Dodds, MR McCoy, A Geldenhuys, et al. Microscale recovery of total lipids from fish tissue by accelerated solvent extraction. Journal of the American Oil Chemists 'Society. 2004;81(9):835-840.

86. N Bodin, HBudzinski, K Le Ménach, et al. ASE extraction method for simultaneous carbon and nitrogen stable isotope analysis in soft tissues of aquatic organisms. Analytica Chimica Acta. 2009;643(1-2):54-60.

87. L Ramos, E Kristenson, UAT Brinkman. Current use of pressurised liquid extraction and subcritical water extraction in environmental analysis. Journal of Chromatography A.2002;975(1):3-29.

88. P Wang, Q Zhang, Y Wang, et al. Evaluation of Soxhlet extraction, accelerated solvent extraction and microwave-assisted extraction for the determination of polychlorinated biphenyls and polybrominated diphenyl ethers in soil and fish samples. Analytica Chimica Acta. 2010;663(1):4348.

89. HP Vasantha Rupasinghe, P Kathirvel, GM Huber. UltrasonicationAssisted solvent extraction of quercetin glycosides from "idared" apple peels. Molecules. 2011;16(12):9783-9791.

90. S Sathivel, W Prinyawiwatkul, JM King, et al. Microwave-assisted catfish liver oil extraction and fatty acid analysis. Journal of the American Oil Chemists' Society. 2003;80(1):15-20.

91. P Mercer, RE Armenta. Developments in oil extraction from microalgae. European Journal of Lipid Science and Technology. 2011;113(5):539547.

92. MJ Ramalhosa, P Paíga, S Morais, et al. Lipid content of frozen fish:Comparison of different extraction methods and variability during freezing storage. Food Chemistry. 2012;131(1):328-336.

93. T Chimsook, W Wannalangka. Effect of microwave pretreatment on extraction yield and quality of catfish oil in northern Thailand. MATEC Web of Conferences. Edited by Z Guo, G Chang. 2015;35:4001.

94. JY Lee, C Yoo, SY Jun,et al. Comparison of several methods for effective lipid extraction from microalgae. Bioresource Technology. 2010;101(1):S75-S77.

95. AICarrapiso, C García. Development in lipid analysis:Some new extraction techniques and in situ transesterification. Lipids. 2000;35(11):1167-1177. 
96. N Yeddes, JK Chérif, A Jrad, et al. Supercritical SC-CO $\mathrm{S}_{2}$ and Soxhle n-hexane extract of Tunisian opuntia ficus indicaseeds and fatty acids analysis. Journal of Lipids. 2012:1-6.

97. MA Gedi, J Bakar, AA Mariod. Optimization of supercritical carbon dioxide $\left(\mathrm{CO}_{2}\right)$ extraction of sardine (Sardinella lemuru Bleeker) oil using response surface methodology (RSM). Grasas y Aceites. 2015;66(2):7485

98. J Huang, S Sathivel. Purifying salmon oil using adsorption, neutralization, and a combined neutralization and adsorption process. Journal of Food Engineering. 2010;96(1):51-58.

99. S Sathivel. Thermal and flow properties of oils from salmon heads Journal of the American Oil Chemists' Society. 2005;82(2):147-152.

100. CY Lin, RJ Li. Fuel properties of biodiesel produced from the crude fish oil from the soapstock of marine fish. Fuel Processing Technology. 2009;90(1):130-136.

101. JM Oberson, E Campos-Giménez, J Rivière, et al. Application of supercritical fluid chromatography coupled to mass spectrometry to the determination of fat-soluble vitamins in selected food products. Journal of Chromatography B. 2018;1086:118-129.

102. S Kuvendziev, K Lisichkov, Z Zeković,et al. Supercritical fluid extraction of fish oil from common carp (Cyprinus carpio L.) tissues. The Journal of Supercritical Fluids. 2018;133:528-534.

103. SC Hathwar, B Bijinu, AK Rai, et al. Simultaneous recovery of lipids and proteins by enzymatic hydrolysis of fish industry waste using different commercial proteases. Applied Biochemistry and Biotechnology. 2011;164(1):115-124.

104. S Sarrade, GM Rios, M Carlés, M. Nanofiltration membrane behavior in a supercritical medium.Journal of Membrane Science. 1996;114(1):81-91.

105. N Rubio-Rodríguez, SMde Diego, S Beltrán, et al.Supercritical fluid extraction of fish oil from fish by-products:A comparison with other extraction methods. Journal of Food Engineering. 2012;109(2):238-248.

106. TB Zou, Q Jia, HW Li, et al. Response surface methodology for ultrasoundassisted extraction of astaxanthin from Haematococcus pluvialis.Marine Drugs. 2013;11(5):1644-1655.

107. L Wang. Advances in extraction of plant products in nutraceutical processing. In Handbook of Nutraceuticals Volume II. CRC Press, 15-52. 2011.

108. DT Santos, R Vardanega, MA De Almeida. Intensification of bioactive compounds extraction from medicinal plants using ultrasonic irradiation. Pharmacognosy Reviews. 2014;8(16):88.

109. Y Picó. Ultrasound-assisted extraction for food and environmental samples. TrAC Trends in Analytical Chemistry. 2013;43:84-99.

110. M Macías-Sánchez, C Mantell, M Rodríguez, et al.Comparison of supercritical fluid and ultrasound-assisted extraction of carotenoids and chlorophyll a from Dunaliella salina. Talanta. 2009;77(3):948-952.

111. W Kong, N Liu, J Zhang,et al. Optimization of ultrasound-assisted extraction parameters of chlorophyll from Chlorella vulgaris residue after lipid separation using response surface methodology. Journal of Food Science and Technology. 2014;51(9):2006-2013.

112. R Natarajan, WM Ang, $X$ Chen, et al. Lipid releasing characteristics of microalgae species through continuous ultrasonication. Bioresource Technology. 2014;158:7-11.

113. M Plaza, S Santoyo, L Jaime, et al. Comprehensive characterization of the functional activities of pressurized liquid and ultrasound-assisted extracts from Chlorella vulgaris. LWT - Food Science and Technology. 2012;46(1):245-253.

114. C Grosso, P Valentão, F Ferreres, et al. Alternative and efficient extraction methods for marine-derived compounds. Marine Drugs. 2015;13(5):3182-3230.
115. MB Latheef. Pulsed ultrasound-assisted solvent extraction of oil from soybeans and microalgae. Masters of Science. Department of Bioresource Engineering. McGill University. 2012.

116. S Abdullah, SKA Mudalip, S Shaarani, et al. Ultrasonic extraction of oil from monopterus albus:effects of different ultrasonic power, solvent volume and sonication time. Journal of Applied Sciences. 2010;10(21):2713-2716.

117. L Xiao, Y Ji, Z Yu, et al. Ultrasound-assisted extraction of bighead carp viscera oil and its physiochemical properties. Journal of Jishou University (Natural Sciences Edition). 2017;38(1):49-55.

118. M Khoei, F Chekin. The ultrasound-assisted aqueous extraction of rice bran oil. Food Chemistry. 2016;194:503-507.

119. AOAC. Official Methods of Analysis. $20^{\text {th }}$ edn. In: Edited et al., editors. Washington, DC, USA: Association of Official Analytical Chemists; 2016.

120. F Sampalis, R Bunea, MF Pelland, et al. Evaluation of the effects of Neptune Krill Oil on the management of premenstrual syndrome and dysmenorrhea. Alternative medicine review: a journal of clinical therapeutic. 2003;8(2):171-179.

121. A Beaudoin, M Geneviéve. Method of extracting lipids from marine and aquatic animal tissues. United States. 2004.

122. AE Ghaly, V Ramakrishnan. Extraction of oil from mackerel fish processing waste using alcalase enzyme.Enzyme Engineering. 2013;2(2):1-10.

123. EM Antolín, DM Delange, VG Canavaciolo. Evaluation of five methods for derivatization and GC determination of a mixture of very long chain fatty acids (C24:0-C36:0). Journal of Pharmaceutical and Biomedical Analysis. 2008;46(1):194-199.

124. AP Martins, NS Yokoya, P Colepicolo. Comparison of extraction and transesterification methods on the determination of the fatty acid contents of three Brazilian seaweed species.Revista Brasileira de Farmacognosia. 2012;22(4):854-860.

125. Y Tang, Y Zhang, J Rosenberg, et al.Optimization of one-step in situ transesterification method for accurate quantification of EPA in Nannochloropsis gaditana. Applied Sciences. 2016;6(11):343.

126. S Meier, SA Mjøs, H Joensen, et al. Validation of a one-step extraction/ methylation method for determination of fatty acids and cholesterol in marine tissues.Journal of Chromatography A. 2006;1104(1-2):291-298.

127. Q Gu, F David, F Lynen, et al. Evaluation of ionic liquid stationary phases for one dimensional gas chromatography-mass spectrometry and comprehensive two dimensional gas chromatographic analyses of fatty acids in marine biota. Journal of Chromatography A. 2011;1218(20):30563063 .

128. WW Christie. Gas Chromatography and Lipids: A Practical Guide. First Edit. In: JT Bernert editor. Ayr, United Kingdom: Oil Press; 1989.

129. IL Figueiredo, T Claus, O Oliveira Santos Júnior, et al. Fast derivatization of fatty acids in different meat samples for gas chromatography analysis. Journal of Chromatography A. 2016;1456:235-241.

130. CW Moss, MA Lambert, WH Merwin. Comparison of rapid methods for analysis of bacterial fatty acids. Applied microbiology. 1974;28(1):80-85.

131. RG Ackman. Remarks on official methods employing boron trifluoride in the preparation of methyl esters of the fatty acids of fish oils. Journal of the American Oil Chemists'Society. 1998;75(4):541-545.

132. M Zhang, X Yang, HT Zhao, et al. A quick method for routine analysis of C18 trans fatty acids in non-hydrogenated edible vegetable oils by gas chromatography-mass spectrometry. Food Control. 2015;57:293-301.

133. ISO 12966-2. Animal and vegetable fats and oils - Gas chromatography of fatty acid methyl esters - Part 2: Preparation of methyl esters of fatty acids. 2017. 
134. P Araujo, TT Nguyen, L Frøyland, et al. Evaluation of a rapid method for the quantitative analysis of fatty acids in various matrices. Journal of Chromatography A. 2008;1212(1-2):106-113.

135. C Stavarache, M Vinatoru, Y Maeda. Ultrasonic versus silent methylation of vegetable oils. Ultrasonics Sonochemistry. 2006;13(5):401-407.

136. WW Christie. Advances in Lipid Methodology. USA: Oil Press; 1993. P. 69-111.

137. JL Guil-Guerrero, E Venegas-Venegas, MA Rincón-Cervera, et al. Fatty acid profiles of livers from selected marine fish species. Journal of Food Composition and Analysis. 2011;24(2):217-222.

138. J Rodríguez-Ruiz, El-H Belarbi, JL García Sánchez, et al. Rapid simultaneous lipid extraction and transesterification for fatty acid analyses. Biotechnology Techniques. 1998;12(9):689-691.

139. B Homayooni, MA Sahari, M Barzegar. Concentrations of omega-3 fatty acids from rainbow sardine fish oil by various methods. International Food Research Journal. 2014;21(2):743-748.

140. JD Joseph, RG Ackman. Capillary column gas chromatographic method for analysis of encapsulated fish oils and fish oil ethyl esters:Collaborative study. Journal of AOAC (Association of Official Analytical Chemists) International. 1992;75(3):488-506.

141. N Abd Aziz, A Azlan, A Ismail, et al. Quantitative determination of fatty acids in marine fish and shellfish from warm water of straits of Malacca for nutraceutical purposes. BioMed Research International. 2013:1-12.

142. EL Maia, DB Rodriguez-Amaya. Avaliaçäo de um método simples e econômico para a metilaçäo de ácidos graxos com lipídios de diversas espécies de peixes / Evaluation of a simple and inexpensive method for the methylation of fatty acid with lipids of various fish species. Rev. Inst. Adolfo Lutz. 1993:53(1/2):27-35.

143. JL Guil-Guerrero, JC López-Martínez, MA Rincón-Cervera, et al. Onestep extraction and concentration of polyunsaturated fatty acids from fish liver. Journal of the American Oil Chemists 'Society. 2007;84(4):357-361.

144. Z Xu, K Harvey, T Pavlina, et al. An improved method for determining medium- and long-chain FAMEs using gas chromatography. Lipids. 2010;45(2):199-208.
145. G Lepage, CC Roy. Improved recovery of fatty acid through direct transesterification without prior extraction or purification. Journal of lipid research. 1984;25(12):1391-1396.

146. G Lepage, CC Roy. Direct transesterification of all classes of lipids in a one-step reaction. Journal of lipid research. 1986;27(1):114-20.

147. A Masood, KD Stark, N Salem. A simplified and efficient method for the analysis of fatty acid methyl esters suitable for large clinical studies. Journal of Lipid Research. 2005;46(10):2299-2305.

148. V Fournier, F Destaillats, P Juanéda, et al. Thermal degradation of long-chain polyunsaturated fatty acids during deodorization of fish oil. European Journal of Lipid Science and Technology. 2006;108(1):33-42.

149. LML Laurens, M Quinn, S Van Wychen, et al. Accurate and reliable quantification of total microalgal fuel potential as fatty acid methyl esters by in situ transesterification. Analytical and Bioanalytical Chemistry. 2012;403(1):167-178.

150. A Laffargue, A de Kochko, S Dussert. Development of solid-phase extraction and methylation procedures to analyse free fatty acids in lipidrich seeds.Plant Physiology and Biochemistry. 2007;45(3-4):250-257.

151. A Rawyler, D Pavelic, C Gianinazzi, et al. Membrane lipid integrity relies on a threshold of ATP production rate in potato cell cultures submitted to anoxia. Plant Physiology. 1999;120(1):293-300.

152. M Sacandé, FA Hoekstra, AC van Aelst, et al. Is oxidative stress involved in the loss of neem (Azadirachta indica) seed viability? Seed Science Research. 2000;10(3):381-392.

153. WW Christie. Preparation of ester derivatives of fatty acids for chromatographic analysis. In WW Christie (ed.) Advances in Lipid Methodology - Two. Dundee, Scotland:Oily Press LTD; 1993. P. 69-111.

154. J Zeng, X Wang, B Zhao, et al. Rapid in situ transesterification of sunflower oil. Industrial \& Engineering Chemistry Research. 2009;48(2):850-856. 